\title{
In vitro assessment of edoxaban anticoagulant effect in pediatric plasma.
}

Thomas Sinegre, PharmD ${ }^{1,2}$, Mélissa Zlobecki ${ }^{1}$, Eric Doré, $\mathrm{MD}^{3}$, Bruno Pereira ${ }^{4}$ Victoria Grèze, $\mathrm{MD}^{3}$, Aurélien Lebreton $\mathrm{MD}, \mathrm{PhD}^{1,2}$

Affiliations: ${ }^{1} \mathrm{CHU}$ Clermont-Ferrand, Service d'Hématologie Biologique, ClermontFerrand, France; '2Université Clermont Auvergne, INRA UMR 1019, ClermontFerrand, France; ${ }^{3} \mathrm{CHU}$ Clermont-Ferrand, Service d'Hématologie Oncologie Pédiatrique, Clermont-Ferrand, France; ${ }^{4} \mathrm{CHU}$ Clermont-Ferrand, Direction de la recherche clinique, Clermont-Ferrand France

Corresponding author: Thomas Sinegre, Service d'Hématologie Biologique, CHU Estaing, 1 place Lucie et Raymond Aubrac, 63100 Clermont-Ferrand, France. Tel: +33 473750 200; Fax: +33 473750 215; e-mail: tsinegre@chu-clermontferrand.fr

Declaration of interest: none.

Word count: 3764 


\section{Abstract}

\section{Introduction}

Anticoagulant therapy in pediatric patients remains an issue and safer therapies, such as direct oral anticoagulants could overcome the limitations of conventional anticoagulant treatments in this population. Edoxaban, a factor Xa inhibitor, is used for the prevention and treatment of venous thromboembolism. Due to its pharmacokinetic characteristics, edoxaban is a promising candidate molecule for children. This study compared edoxaban in vitro effect in children and adults.

\section{Materials and Methods}

Blood samples were prospectively collected from 87 adults and 97 children $(n=12$ : $<2$ year-old; $n=8: 2-4$ year-old; $n=9: 5-7$ year-old; $n=14: 8-9$ year-old; $n=10: 10-13$ year-old; $n=15:$ 14-15 year-old; and $n=29: 16-18$ year-old). Plasma samples were supplemented in vitro with edoxaban to a final concentration of 50,150 or 300 $\mathrm{ng} / \mathrm{mL}$, and then edoxaban effect on prothrombin time (PT), activated partial thromboplastin time (aPTT), fibrinogen (Clauss assay), specific anti-factor Xa activity and thrombin generation assay (TGA) (with 5pM tissue factor and 4nM phospholipids) was evaluated.

\section{Results}

PT, aPTT, and specific anti-Xa activity exhibited similar dose-dependent responses to edoxaban in the different age groups. The reduction of thrombin peak, the most edoxaban-sensitive TGA parameter, was similar in adults and children, but for the youngest group (<2 year-old) where the peak value reduction (median [Q1-Q3]) was higher than in adults (51\% [44-59] versus 40\% [32-46], $\mathrm{p}<0.01 ; 74 \%$ [63-80] versus 65\% 
[58-70], $\mathrm{p}<0.05$; and $84 \%$ [73-88] versus $76 \%$ [70-80], $\mathrm{p}<0.05$ for 50,150 and $300 \mathrm{ng} / \mathrm{mL}$ edoxaban, respectively).

\section{Conclusions}

Edoxaban in vitro effect are comparable in children and adults except in the $<2$ year-old group.

Keywords: Coagulation, Edoxaban, Pediatric, Thrombin generation

Abbreviations: PT: Prothrombin time; APTT: Activated partial thromboplastin time; ETP: Endogenous thrombin potential; LMWH: Low molecular weight heparin; TGA:

Thrombin generation assay; UFH: Unfractionated heparin; VKA: vitamin K antagonists; VTE: Venous thromboembolism 


\section{Introduction}

The incidence of venous thromboembolism (VTE) in hospitalized children has strongly increased during the last decades, regardless of their age class. ${ }^{1,2}$ The most common anticoagulant therapies used in this population are multi-target compounds, such as unfractionated heparin (UFH), low molecular weight heparins (LMWH) and vitamin $\mathrm{K}$ antagonists (VKA) ${ }^{3-5}$ However, their use is associated with important drawbacks, particularly in pediatric populations. VKA management requires strict monitoring ${ }^{6}$ and the availability of a liquid formulation. UFH treatment requires injections and monitoring because of the variable pharmacokinetic profile. Similarly, LMWH are not available in oral formulation and require a regular follow-up in pediatric populations. Their effect cannot be easily reversed with protamine. ${ }^{7,8}$

The concept of developmental hemostasis should be integrated when an anticoagulant is required in pediatric patients. Several studies have shown that vitamin K-dependent factors (factor II, VII, IX and X) and contact-phase factors tend to gradually increase from birth and reach adult values around 6 months of age. Conversely, fibrinogen and factor V, VIII and XIII levels at birth are comparable with the adult levels. At birth, the levels of protein $\mathrm{C}$, protein $\mathrm{S}$ and antithrombin are lower, whereas those of alpha-2-macroglobulin are higher compared with adults. ${ }^{9-16}$ These proteins reach adult levels after few months or few years. Despite these differences in the concentration of coagulation factors, there is no evidence that children are more susceptible to coagulation abnormalities, such as bleeding or thrombosis. ${ }^{17}$ However, the effects of anticoagulant drugs on hemostasis are affected by these developmental differences, ${ }^{18}$ and this could lead to variable and potentially dangerous responses in pediatric populations. Importantly, these pharmacodynamic 
changes could be overlooked because monitoring is done using tests based on adult data that do not take into account these developmental differences.

Edoxaban tosylate (edoxaban) is a direct oral anticoagulant that inhibits factor Xa. In adults, edoxaban is indicated for reducing the risk of stroke and systemic embolism in patients with non-valvular atrial fibrillation ${ }^{19}$ and for the prevention or treatment of deep vein thrombosis and pulmonary embolism after parenteral anticoagulants for 510 days. ${ }^{20}$ Edoxaban is currently not approved for anticoagulation in patients younger than 18 years of age. However, its oral administration route, interaction with few drugs and food, and antithrombin level-independent anti-Xa inhibition are interesting features for pediatric use.

Here, we compared the hemostatic response and coagulation assay results in plasma samples from adults and children (different age classes) spiked in vitro with specific concentrations of edoxaban.

\section{Materials and Methods}

\section{Pediatric and adult populations}

For this study, 87 adults ( $>18$ years of age) and 97 children ( $\leq 18$ years of age) were prospectively enrolled at Clermont-Ferrand University Hospital between January 2016 and November 2017. This study was approved by the local ethics committee (AU765, Sud-Est VI France). Exclusion criteria for adults and children were: ongoing antiplatelet or anticoagulant therapy, personal history of bleeding or VTE, and coagulation disorders [fibrinogen $<2 \mathrm{~g} / \mathrm{L}$, prothrombin time $(\mathrm{PT})>17 \mathrm{~s}$, activated partial thromboplastin time $(\mathrm{aPTT})>50$ s]. Children were separated in different age 
groups to take into account the developmental coagulation changes: $<2$ years, $2-4$ years, 5-7 years, 8-9 years, 10-13 years, $14-15$ years and $16-18$ years of age.

\section{Blood sampling and plasma preparation}

Blood was collected by venipuncture in $0.109 \mathrm{M}$ citrate tubes (Beckton Dickinson, le Pont de Claix, France) after discarding the first few milliliters of blood. Corn trypsin inhibitor, an inhibitor of contact phase was not added because coagulation in the thrombin generation assay (TGA) was initiated by addition of $5 \mathrm{pM}$ tissue factor, a concentration that makes irrelevant the inhibition of contact phase. ${ }^{21}$ Platelet-poor plasma (PPP) required for TGA was obtained by centrifuging the blood samples twice $\left(2500 \mathrm{~g}\right.$ at $20^{\circ} \mathrm{C}$ for $\left.15 \mathrm{~min} / \mathrm{each}\right)$ with an intermediate decantation, according to the guidelines of the International Society on Thrombosis and Haemostasis (ISTH). ${ }^{22}$ Samples were stored at $-80{ }^{\circ} \mathrm{C}$ until testing. Then, frozen plasma samples were thawed in a water bath at $37^{\circ} \mathrm{C}$ for 5 minutes.

Edoxaban stock solution $(1.0 \mathrm{mg} / \mathrm{ml}$ in dimethyl sulfoxide) was diluted with phosphate buffered saline (PBS) to $5000 \mathrm{ng} / \mathrm{ml}, 15000 \mathrm{ng} / \mathrm{ml}$ and $30000 \mathrm{ng} / \mathrm{mL}$ working solutions that were added to the plasma samples to reach the target concentrations (50, 150 and 300 $\mathrm{ng} / \mathrm{mL}$ ) with a constant $1 / 100$ dilution. An equivalent volume of PBS was added to baseline samples $(0 \mathrm{ng} / \mathrm{ml})$.

\section{Coagulation assays}

Coagulation assays were performed with a STA-R Max coagulometer (Stago, Asnièressur-Seine, France) using the following reagents (all from Stago): Neoplastin $\mathrm{Cl}^{\circledR}{ }^{\circledR}$ for PT, PTT-A ${ }^{\circledR}$ for aPTT, and STA-Fibrinogen ${ }^{\circledR}$ for fibrinogen (Clauss method). Edoxaban levels in plasma were measured using an anti-factor Xa activity assay (STA®-Liquid Anti- 
Xa, Stago) and the STA®-Edoxaban Calibrator and STA®-Edoxaban Control on a STA®-R analyzer (Stago).

TGAs were performed using the CAT method ${ }^{23}$ with a fluorometer (Fluoroscan Ascent, ThermoLab Systems, Franklin, USA) equipped with a dispenser. Coagulation was initiated with $5 \mathrm{pM}$ tissue factor in the presence of $4 \mu \mathrm{M}$ procoagulant phospholipids (PPP reagent ${ }^{\circledR}$, Stago). For each sample, calibration was performed with the Thrombin calibrator ${ }^{\circledR}$ (Stago). All plates (Immulon 2HB, Waltham, USA) were incubated at $37^{\circ} \mathrm{C}$ for 10 minutes before adding the fluorogenic substrate and $\mathrm{CaCl}_{2}\left(\mathrm{FluCa}-\mathrm{kit}^{\circledR}\right.$, Thrombinoscope BV). All tests were performed in duplicate with a $<10 \%$ difference between endogenous thrombin potential (ETP) results. Raw data were analyzed using Thrombinoscope ${ }^{\mathrm{TM}}$. For each assay, ETP (nM.min) and thrombin peak (nM) were the primary endpoints. The first represents the whole thrombin generated in a plasma sample, and the second the highest thrombin concentration that can be generated and that is particularly affected by edoxaban. Edoxaban effect on ETP and thrombin peak was also expressed as percent inhibition that corresponded for each patient to (1- (ETP in the presence of edoxaban divided by the patient's baseline ETP)) $x 100$.

Statistical analysis

Sample size was estimated according to (i) the CONSORT 2010 statement, extension to randomized pilot and feasibility trials and (ii) Cohen's recommendations, which define effect-size bounds as follows: small (ES: 0.2), medium (ES: 0.5) and large (ES: 0.8, "grossly perceptible and therefore large"). More precisely, an effect size greater than 1.2 (accordind to pilot data) could be highlighted for a two-sided type I error at 0.001 (correction due to multiple comparisons) and a statistical power greater than $80 \%$, with at least 75 adults and 
15 children by group. Effect-size of the difference between children and adults are expressed by coefficient of Hedges $g$ [95\% confidence interval].

Statistical analysis was performed using the Prism software, version 6 (GraphPad software, Inc., La Jolla, USA). Tests were two-sided, with a type I error set at $\alpha=0.05$. Continuous data were presented as medians [Q1-Q3]. Independent groups were compared using ANOVA, or the Kruskal-Wallis test when the ANOVA conditions were not met (normality and homoscedasticity verified with the Bartlett test). Dependent groups were compared using ANOVA or the Friedman test, followed by the appropriate multiplecomparison post-hoc, Tukey-Kramer, or Dunn test.

\section{Results}

Eighty-seven adults and 97 children $(<2$ years of age: $n=12 ; 2-4$ years: $n=8 ; 5-7$ years: $n=9$; $8-9$ years: $n=14 ; 10-13$ years: $n=10 ; 14-15$ years: $n=15$; and $16-18$ years: $n=29$ ) were included in the study. Their demographic characteristics are summarized in Table 1.

Routine coagulation and specific anti-Xa assays

Overall (pediatric and adult samples together), the impact of edoxaban on clotting times increased in a dose-dependent manner. PT $(n=56)$ increased from 13.3s [12.7-13.9] to $14.2 \mathrm{~s}$ [13.5-15.3], 17.0s [16.4-18.5] and 21.7s [20.1-23.0] for vehicle, 50, 150 and 300 $\mathrm{ng} / \mathrm{mL}$ edoxaban, respectively, and aPTT $(\mathrm{n}=59)$ from $35.5 \mathrm{~s}$ [32.6-39.8] to 38.8s [34.743.4], 44.2s [39.5-50.3] and 50.3s [43.7-56.1], respectively. Although, the PT and aPTT values showed a linear response to edoxaban, they were relatively insensitive to the increasing concentrations of edoxaban, as indicated by their 1.6-fold and 1.4-fold increase, 
respectively, from baseline to $300 \mathrm{ng} / \mathrm{mL}$ edoxaban. Conversely, edoxaban had no effect on fibrin clot formation (fibrinogen assay) ( $\mathrm{n}=50)$ with fibrinogen concentrations of $3.2 \mathrm{~g} / \mathrm{L}$ [2.7-4.0], 3.3 g/L [3.0-3.9], 3.3 g/L [2.9-3.9], and 3.2 g/L [2.7-3.9] for vehicle, 50, 150 and $300 \mathrm{ng} / \mathrm{mL}$ edoxaban, respectively.

When these results were compared in the different age groups, PT, aPTT and fibrinogen concentration were comparable in the adult and pediatric populations before and after edoxaban addition and for all the drug concentrations (Table 2 and Figure 1; available online).

When edoxaban level in plasma samples was measured using a specific anti-factor Xa assay, the concentrations were comparable to those expected on the basis of the in vitro spiking, without any age-related difference (Figure 2; available online).

\section{Thrombin generation assay}

Overall (pediatric and adult samples together), edoxaban led to major changes in thrombin generation profile in a dose-dependent manner. The lag time, which corresponds to the time required to generate the first thrombin traces, gradually increased with edoxaban concentration. Lag time was sensitive to edoxaban anticoagulant effect, as indicated by the 3-fold increase for $300 \mathrm{ng} / \mathrm{mL}$ edoxaban compared with baseline. Similarly, time to peak significantly increased in a dose-dependent manner. ETP (maximum decrease of $40 \%$ at $300 \mathrm{ng} / \mathrm{mL}$ ) and particularly thrombin peak (reduction by $80 \%$ at $300 \mathrm{ng} / \mathrm{m}$ ) also were affected by edoxaban in a dose-dependent manner. The thrombin generation curve was altered by in vitro addition of edoxaban with a delay in the initiation phase, and a flattening of the curve leading to a plateau, especially from $150 \mathrm{ng} / \mathrm{mL}$ of edoxaban, due to the significant decrease in thrombin peak (Figure 3). ETP was significantly and linearly 
affected by edoxaban concentration, whereas the thrombin peak decreased sharply at 50 $\mathrm{ng} / \mathrm{mL}$ (approximately by 50\%) and then less markedly (Figure 4).

In the different age groups, at baseline, lag time ranged from 3.0min [2.7-3.7] in the <2year age group to 3.2min [2.7-3.7] in adults $(p=0.128)$. Similarly, baseline time to peak (about $6 \mathrm{~min}$ ) hardly changed in the different age groups $(p=0.31)$. Conversely, ETP and thrombin peak were significantly influenced by age with lower values during the first years of life. Starting from 8 years of age, thrombin generation parameters were comparable in adults and children (Table 3 ).

In vitro addition of edoxaban, irrespectively of the concentration, did not differentially affect lag time and time to peak in the different age groups. Overall, for all age groups, including adults, lag time increased by 1.7-fold, 2.3-fold and 3.0-fold, and time to peak by 1.7-fold, 2.6-fold and 3.1-fold, upon addition of 50, 150 and $300 \mathrm{ng} / \mathrm{mL}$ edoxaban, respectively.

Lower ETP values during the first years of life were observed also after in vitro addition of edoxaban. Upon addition of $50 \mathrm{ng} / \mathrm{mL}$ edoxaban, ETP was $1296 \mathrm{nM}$.min [1144-1466] in adults, 979 nM.min [760-1099] in the $<2-$ year $(p<0.001, \mathbf{g}=-1.7[-2.5 ;-0.8]$ compared with

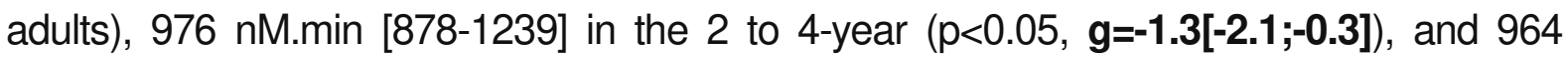
nM.min [873-1083] in the 5 to 7-year age group $(p<0.01, \mathbf{g}=-1.5[-2.3 ;-0.6])$. After addition of $150 \mathrm{ng} / \mathrm{mL}$ edoxaban, ETP was 1108 nM.min [933-1225] in adults, 750 nM.min [496$946]$ in the $<2-$ year $(p<0.001, \mathbf{g}=-1.6[-2.4 ;-0.8]), 815$ nM.min [585-1027] in the 2 to 4-year $(p<0.05, \mathbf{g}=-1.2[-2.1 ;-0.3])$, and 861 nM.min [761-949] in the 5 to 7-year age group $(\mathrm{p}<0.05, \mathbf{g}=-\mathbf{1 . 1}[-\mathbf{1 . 8} ;-\mathbf{0 . 2}])$. Finally, upon addition of $300 \mathrm{ng} / \mathrm{mL}$ edoxaban, ETP values ranged from 928 nM.min [692-1079] in adults to 572 nM.min [333-735] in the <2-year $(p<0.001, \mathbf{g}=-1.5[-2.2 ;-0.7]), 660$ nM.min [490-823] in the 2 to 4-year $(p<0.05, \mathbf{g}=-1.1[-2.0 ;-$ 0.2]), and 702 nM.min [611-814] in the 5 to 7 -year age group $(p=0.23, \mathbf{g}=-0.8[-1.6 ;-0.1])$. 
Thrombin peak also was significantly lower in the <2-year age group after in vitro addition of edoxaban (Table 3 and Figure 4).

Edoxaban-mediated thrombin-generation inhibition was relatively stable in the different age groups. The percentage of ETP inhibition varied between 8 and 13\% according to the age group $(p=0.73)$ for $50 \mathrm{ng} / \mathrm{mL}$, between 25 and $35 \%(p=0.29)$ for $150 \mathrm{ng} / \mathrm{mL}$, and between 37 and $54 \%(p=0.08)$ for $300 \mathrm{ng} / \mathrm{mL}$ edoxaban. The percentage of thrombin peak inhibition by edoxaban was similar between adults and children, but for the $<2$-year age group where edoxaban-mediated inhibition was more pronounced than in adults (51\% [44-59] vs $40 \%$ [32-46], $\mathrm{p}<0.01, \mathrm{~g}=1.0[0.3 ; 1.7] ; 74 \%$ [63-80] vs $65 \%$ [58-70], $p<0.05, g=0.4[0.2 ; 1.1]$; and $84 \%$ [73-88] vs $76 \%[70-80], p<0.05, g=0.8[0.1 ; 1.4]$, for 50 , 150 and $300 \mathrm{ng} / \mathrm{mL}$ edoxaban respectively) (Figure 5). These results indicate that edoxaban affects ETP evenly across the different age groups, but has a stronger inhibition effect on the thrombin peak in young children.

\section{Discussion}

The present study investigated for the first time the in vitro effect of edoxaban, a direct and reversible factor Xa inhibitor, in different pediatric age groups and in adults. PT, aPTT, and the specific anti-Xa anticoagulant activity showed a similar dose-dependent response to edoxaban in the different age groups. Inhibition of thrombin peak, the most edoxaban-sensitive TGA parameter, was similar between adults and children, except for the youngest age group ( $<2$ years).

The recommended edoxaban dose in adults for prevention or treatment of deep vein thrombosis and pulmonary embolism (i.e., $60 \mathrm{mg} /$ daily) should give a maximum plasma concentration between 152 and $302 \mathrm{ng} / \mathrm{mL}$, and trough plasma concentrations that rarely 
exceed $50 \mathrm{ng} / \mathrm{mL}^{24}$ Therefore, the plasma concentrations used in our study (i.e., 50, 150 and $300 \mathrm{ng} / \mathrm{mL}$ ) were adequate to the expected exposure in patients treated with the usual dose. Our results showed similar coagulation times in the different age groups for the classical coagulation tests (PT, aPTT and fibrinogen assay). These data are consistent with previous findings, ${ }^{12,15,16}$ although some studies found a variable lengthening according to age. ${ }^{9,13,14}$ When we used conventional coagulation tests, edoxaban spiking led to PT increase in both adult and pediatric plasma samples in a concentrationdependent and linear manner, with low sensitivity (particularly at low concentrations). This effect could vary depending on the thromboplastin used. Similar results were obtained for aPTT. These data are comparable with edoxaban effects in adults ${ }^{25-27}$ Therefore, conventional assays, such as PT or aPTT, do not seem to be adapted to monitor the hemostasis changes during development. On the other hand, TGA is considered to be an innovative way to understand coagulation globally, especially when it is disturbed by complex changes that alter the coagulation balance, for instance in developmental hemostasis. Several studies indicate that TGA is a relevant tool to identify prothrombotic or hypocoagulable conditions ${ }^{28-31}$ TGA allowed highlighting the baseline decrease in thrombin generation in pediatric plasma samples, particularly the lower ETP and thrombin peak in children younger than 8 years of age. These data are consistent with several studies that reported a marked reduction in thrombin generation in children, including an inverse correlation between age and ETP or thrombin peak. ${ }^{17,32-34}$

Edoxaban inhibited thrombin generation in a dose-dependent manner. The thrombin peak appeared to be the most sensitive parameter with $50 \%$ inhibition with $50 \mathrm{ng} / \mathrm{mL}$ edoxaban, followed by a plateau at $150 \mathrm{ng} / \mathrm{mL}$, while ETP inhibition was more linear. These findings are consistent with literature data on TGA in adults. ${ }^{35,36}$ ETP was inhibited by edoxaban 
uniformly in all age groups. Conversely thrombin peak was the most age-sensitive parameter. Indeed, whatever the concentration, edoxaban anticoagulant effect was significantly higher in the <2-year age group compared with adults. Therefore, in addition to basically generating less thrombin, these patients would be more sensitive to factor Xa inhibition than adults. Kremers et al. ${ }^{33}$ showed in children a reduction in prothrombin conversion and a concomitant decrease in conversion rates with lower generation of prothrombinase complexes than in adults. Edoxaban may have a synergistic effect because it inhibits both free factor $\mathrm{Xa}$ and within the prothrombinase complex. These data should be taken into account for the definition of edoxaban doses in children.

One of the limitations of this study is the impact of alpha2-macroglobulin, the concentration of which is higher in neonates. Ignjatovic et al. ${ }^{37}$ showed that in most methods used to measure ETP, the substrates could be cleaved also by alpha2-macroglobulin-bound thrombin, which is inactive in vivo, and this could induce a bias in the comparison of adults and children. To overcome this limitation we used the method described by Hemker in which the alpha2-macroglobulin-bound thrombin fraction is estimated and subtracted from the signal. ${ }^{38}$ Only children and adults not requiring anticoagulant therapy were included in our study. Edoxaban effect should also be studied in patients with potentially prothrombotic disorders who are likely to receive anticoagulant therapy. An in vivo clinical study is needed to evaluate edoxaban efficacy and safety, particularly in children younger than 2 years. The number of samples for the different age groups, especially for the youngest children, was small. This is explained by the limited availability of volunteers who matched the inclusion criteria (healthy subject, without anticoagulant therapy), and the difficulty of obtaining blood samples from young children and in sufficient volume for the different tests. Nevertheless, edoxaban response was different in <2-yar-old children 
and it is known that coagulation changes are more important close to birth. A study specifically on this age group would be interesting.

Edoxaban anti-factor Xa activity accurately reflects plasma levels in both children and adults, and its in vitro effects are similar at all ages, with the exception of children younger than 2 years of age in whom the anticoagulant effect is increased.

\section{Acknowledgements}

Authors sincerely thank the technical staff of the Hemostasis Department (University hospital of Clermont-Ferrand) and Elisabetta Andermarcher for English editing.

This study was funded by a grant from Octapharma 


\section{References}

1. Raffini L, Huang Y-S, Witmer C, Feudtner C. Dramatic increase in venous thromboembolism in children's hospitals in the United States from 2001 to 2007. Pediatrics 2009; 124(4):1001-8.

2. Boulet SL, Grosse SD, Thornburg CD, Yusuf H, Tsai J, Hooper WC. Trends in venous thromboembolism-related hospitalizations, 1994-2009. Pediatrics 2012; 130(4):e812-820.

3. Young G. Anticoagulants in children and adolescents. ASH Educ Program Book 2015; 2015(1):111-6.

4. Young G. How I treat pediatric venous thromboembolism. Blood 2017; 130(12):1402-8.

5. Monagle P, Chan AKC, Goldenberg NA, Ichord RN, Journeycake JM, NowakGöttl U, et al. Antithrombotic therapy in neonates and children: Antithrombotic Therapy and Prevention of Thrombosis, 9th ed: American College of Chest Physicians Evidence-Based Clinical Practice Guidelines. Chest 2012; 141(2 Suppl):e737S-e801S.

6. Ageno W, Gallus AS, Wittkowsky A, Crowther M, Hylek EM, Palareti G. Oral anticoagulant therapy: Antithrombotic Therapy and Prevention of Thrombosis, 9th ed: American College of Chest Physicians Evidence-Based Clinical Practice Guidelines. Chest 2012; 141(2 Suppl):e44S-e88S.

7. Garcia DA, Baglin TP, Weitz JI, Samama MM. Parenteral anticoagulants: Antithrombotic Therapy and Prevention of Thrombosis, 9th ed: American College of Chest Physicians Evidence-Based Clinical Practice Guidelines. Chest 2012; 141(2 Suppl):e24S-e43S.

8. Malec L, Young G. Treatment of Venous Thromboembolism in Pediatric Patients. Front Pediatr 2017; 5:26.

9. Andrew M, Paes B, Milner R, Johnston M, Mitchell L, Tollefsen DM, et al. Development of the human coagulation system in the full-term infant. Blood 1987; 70(1):165-72.

10. Attard $C$, van der Straaten $T$, Karlaftis $V$, Monagle $P$, Ignjatovic $V$. Developmental hemostasis: age-specific differences in the levels of hemostatic proteins. J Thromb Haemost JTH 2013; 11(10):1850-4.

11. Monagle P, Massicotte P. Developmental haemostasis: secondary haemostasis. Semin Fetal Neonatal Med 2011; 16(6):294-300.

12. Andrew M, Vegh $P$, Johnston M, Bowker J, Ofosu $F$, Mitchell L. Maturation of the hemostatic system during childhood. Blood 1992; 80(8):1998-2005. 
13. Toulon $P$, Berruyer M, Brionne-François $M$, Grand $F$, Lasne D, Telion $C$, et al. Age dependency for coagulation parameters in paediatric populations. Results of a multicentre study aimed at defining the age-specific reference ranges. Thromb Haemost 2016; 116(1):9-16.

14. Kuhle S, Male C, Mitchell L. Developmental hemostasis: pro- and anticoagulant systems during childhood. Semin Thromb Hemost 2003; 29(4):329-38.

15. Flanders MM, Crist RA, Roberts WL, Rodgers GM. Pediatric reference intervals for seven common coagulation assays. Clin Chem 2005; 51(9):1738-42.

16. Sosothikul D, Seksarn $P$, Lusher JM. Pediatric reference values for molecular markers in hemostasis. J Pediatr Hematol Oncol 2007; 29(1):19-22.

17. Monagle P, Barnes C, Ignjatovic V, Furmedge J, Newall F, Chan A, et al. Developmental haemostasis. Impact for clinical haemostasis laboratories. Thromb Haemost 2006; 95(2):362-72.

18. Ignjatovic $\mathrm{V}$, Mertyn E, Monagle $\mathrm{P}$. The coagulation system in children: developmental and pathophysiological considerations. Semin Thromb Hemost 2011; 37(7):723-9.

19. Giugliano RP, Ruff CT, Braunwald E, Murphy SA, Wiviott SD, Halperin JL, et al. Edoxaban versus warfarin in patients with atrial fibrillation. N Engl J Med 2013; 369(22):2093-104.

20. Hokusai-VTE Investigators, Büller HR, Décousus H, Grosso MA, Mercuri M, Middeldorp S, et al. Edoxaban versus warfarin for the treatment of symptomatic venous thromboembolism. N Engl J Med 2013; 369(15):1406-15.

21. van Veen JJ, Gatt A, Cooper PC, Kitchen S, Bowyer AE, Makris M. Corn trypsin inhibitor in fluorogenic thrombin-generation measurements is only necessary at low tissue factor concentrations and influences the relationship between factor VIII coagulant activity and thrombogram parameters. Blood Coagul Fibrinolysis Int J Haemost Thromb 2008; 19(3):183-9.

22. Subcommittee on Control of Anticoagulation of the SSC of the ISTH. Towards a recommendation for the standardization of the measurement of plateletdependent thrombin generation. J Thromb Haemost 2011; 9(9):1859-61.

23. Hemker HC, Giesen P, AIDieri R, Regnault V, de Smed E, Wagenvoord R, et al. The calibrated automated thrombogram (CAT): a universal routine test for hyper- and hypocoagulability. Pathophysiol Haemost Thromb 2002; 32(56):249-53.

24. Ogata K, Mendell-Harary J, Tachibana M, Masumoto H, Oguma T, Kojima M, et al. Clinical safety, tolerability, pharmacokinetics, and pharmacodynamics of the novel factor Xa inhibitor edoxaban in healthy volunteers. J Clin Pharmacol 2010; 50(7):743-53. 
25. Douxfils J, Ageno W, Samama C-M, Lessire S, Ten Cate H, Verhamme P, et al. Laboratory testing in patients treated with direct oral anticoagulants: a practical guide for clinicians. J Thromb Haemost JTH 2018; 16(2):209-19.

26. Morishima $\mathrm{Y}$, Kamisato $\mathrm{C}$. Laboratory measurements of the oral direct factor $\mathrm{Xa}$ inhibitor edoxaban: comparison of prothrombin time, activated partial thromboplastin time, and thrombin generation assay. Am J Clin Pathol 2015; 143(2):241-7.

27. Samuelson BT, Cuker A, Siegal DM, Crowther M, Garcia DA. Laboratory Assessment of the Anticoagulant Activity of Direct Oral Anticoagulants: A Systematic Review. Chest 2017; 151(1):127-38.

28. Al Dieri R, Peyvandi F, Santagostino E, Giansily M, Mannucci PM, Schved JF, et al. The thrombogram in rare inherited coagulation disorders: its relation to clinical bleeding. Thromb Haemost 2002; 88(4):576-82.

29. Castoldi E, Rosing J. Thrombin generation tests. Thromb Res 2011; 127 Suppl 3:S21-25.

30. Hemker HC, Al Dieri R, De Smedt E, Béguin S. Thrombin generation, a function test of the haemostatic-thrombotic system. Thromb Haemost 2006; 96(5):55361.

31. Hron G, Kollars M, Binder BR, Eichinger S, Kyrle PA. Identification of patients at low risk for recurrent venous thromboembolism by measuring thrombin generation. JAMA 2006; 296(4):397-402.

32. Haidl H, Cimenti C, Leschnik B, Zach D, Muntean W. Age-dependency of thrombin generation measured by means of calibrated automated thrombography (CAT). Thromb Haemost 2006; 95(5):772-5.

33. Kremers RMW, Wagenvoord RJ, de Laat HB, Monagle P, Hemker HC, Ignjatovic V. Low paediatric thrombin generation is caused by an attenuation of prothrombin conversion. Thromb Haemost 2016; 115(6):1090-100.

34. Orhon FS, Egin Y, Ulukol B, Baskan S, Akar N. Evaluation of indirect microparticle activity and parameters of thrombin generation test in healthy infants. Thromb Res 2014; 133(2):281-4.

35. Douxfils J, Chatelain B, Chatelain C, Dogné J-M, Mullier F. Edoxaban: Impact on routine and specific coagulation assays. A practical laboratory guide. Thromb Haemost 2016; 115(2):368-81.

36. Samama MM, Mendell J, Guinet C, Le Flem L, Kunitada S. In vitro study of the anticoagulant effects of edoxaban and its effect on thrombin generation in comparison to fondaparinux. Thromb Res 2012; 129(4):e77-82.

37. Ignjatovic V, Greenway A, Summerhayes R, Monagle P. Thrombin generation: the functional role of alpha-2-macroglobulin and influence of developmental haemostasis. Br J Haematol 2007; 138(3):366-8. 
38. Hemker HC, de Smedt E, Al Dieri R. The contribution of alpha(2)-macroglobulin thrombin to the endogenous thrombin potential. $\mathrm{Br} \mathrm{J}$ Haematol 2007; 139(3):513. 
Tables

Table 1: Summary of the participants' demographic characteristics

\begin{tabular}{lcccccccc} 
& $<\mathbf{2} \mathbf{y}$ & $\mathbf{2 - 4} \mathbf{y}$ & $\mathbf{5 - 7} \mathbf{y}$ & $\mathbf{8 - 9} \mathbf{y}$ & $\mathbf{1 0 - 1 3} \mathbf{y}$ & $\mathbf{1 4 - 1 5} \mathbf{y}$ & $\mathbf{1 6 - 1 8} \mathbf{y}$ & adults \\
\hline $\mathrm{n}=$ & 12 & 8 & 9 & 14 & 10 & 15 & 29 & 87 \\
\hline Age & months & \multicolumn{7}{c}{ years } \\
\hline median & 14 & 3 & 7 & 9 & 11 & 15 & 17 & 56 \\
\hline range & $3-23$ & $2-4$ & $5-7$ & $8-9$ & $10-13$ & $14-15$ & $16-18$ & $21-87$ \\
\hline
\end{tabular}

Sex, n (\%)

\begin{tabular}{rrrrrrrrr}
\hline Female & $3(25)$ & $2(25)$ & $1(11)$ & $7(50)$ & $3(30)$ & $11(73)$ & $17(59)$ & $41(47)$ \\
Male & $9(75)$ & $6(75)$ & $8(89)$ & $7(50)$ & $7(70)$ & $4(27)$ & $12(41)$ & $46(53)$ \\
\hline
\end{tabular}

Y: years 
Table 2: Results of coagulation assays using plasma samples from adults and children before and after addition of edoxaban

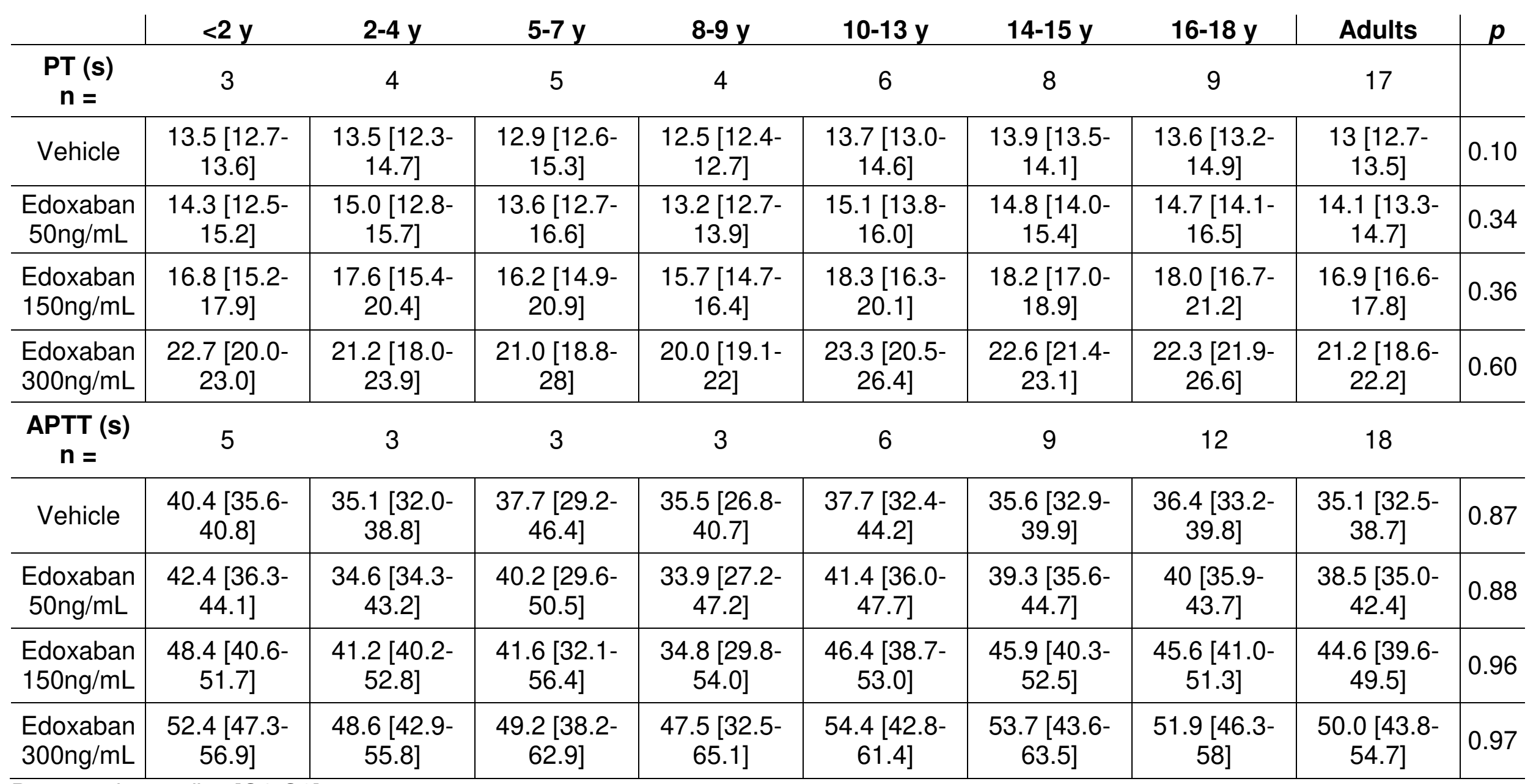

Data are the median [Q1-Q3]

PT: prothrombin time, aPTT: activated partial thrombin time, Y: years.

Edoxaban had no effect on fibrinogen level, and fibrinogen concentration was comparable in adults and children. 
Table 3: Thrombin generation assay results before and after edoxaban addition.

\begin{tabular}{|c|c|c|c|c|c|c|c|c|c|}
\hline & & $\begin{array}{l}<2 \text { yrs } \\
(n=12)\end{array}$ & $\begin{array}{c}2-4 \text { yrs } \\
(n=8)\end{array}$ & $\begin{array}{c}5-7 \text { yrs } \\
(n=9)\end{array}$ & $\begin{array}{l}8-9 \text { yrs } \\
(n=14)\end{array}$ & $\begin{array}{c}10-13 \text { yrs } \\
(n=10)\end{array}$ & $\begin{array}{c}14-15 \text { yrs } \\
(n=15)\end{array}$ & $\begin{array}{c}16-18 \text { yrs } \\
(n=29)\end{array}$ & $\begin{array}{l}\text { Adults } \\
(n=87)\end{array}$ \\
\hline \multirow{4}{*}{$\begin{array}{c}\mathrm{LT} \\
(\min )\end{array}$} & Vehicle & $3.0[2.7-3.7]$ & 3.1 [2.8-3.4] & 3.0 [2.7-3.0] & 3.0 [2.9-3.3] & 3.2 [2.8-3.5] & 3.0 [2.7-3.3] & 2.7 [2.7-3.0] & $3.2[2.7-3.7]$ \\
\hline & $\begin{array}{c}\text { Edoxaban } \\
50 \mathrm{ng} / \mathrm{mL}\end{array}$ & $5.1[4.5-6.2]$ & 5.6 [4.3-5.9] & $5.2[4.4-5.7]$ & $5.0[4.7-5.5]$ & $5.7[5.4-6.4]$ & 5.3 [4.7-6.2] & $5.2[4.4-5.5]$ & $5.2[4.5-5.7]$ \\
\hline & $\begin{array}{l}\text { Edoxaban } \\
150 \mathrm{ng} / \mathrm{mL}\end{array}$ & 7.7 [6.4-8.9] & 7.6 [5.9-8.7] & 7.0 [6.3-8.0] & 7.0 [6.3-8.3] & 8.8 [7.9-9.0] & 7.6 [6.8-8.7] & $7.3[6.0-8.1]$ & 7.0 [6.3-8.5] \\
\hline & $\begin{array}{l}\text { Edoxaban } \\
\text { 300ng/mL }\end{array}$ & $\begin{array}{c}9.6[8.5- \\
11.0]\end{array}$ & 9.3 [7.8-10.6] & 8.7 [8.0-9.8] & $8.7[7.8-10.4]$ & $\begin{array}{c}10.9[10.0- \\
11.9]\end{array}$ & 9.7 [8.6-10.7] & 9.2 [7.5-10.5] & 9.0 [8.0-10.7] \\
\hline \multirow{4}{*}{$\begin{array}{c}\text { ETP } \\
\text { (nM.min) }\end{array}$} & Vehicle & $\begin{array}{c}1094[897- \\
1260]^{* * *}\end{array}$ & $\begin{array}{c}1087[1012- \\
1330]^{\star *}\end{array}$ & $\begin{array}{c}1101[1038- \\
1201]^{* * *}\end{array}$ & $\begin{array}{c}1297[1237- \\
1496]\end{array}$ & $\begin{array}{c}1212[1054- \\
1459]\end{array}$ & $\begin{array}{c}1293[1080- \\
1374]\end{array}$ & $\begin{array}{c}1259 \text { [1156- } \\
1695]\end{array}$ & $\begin{array}{c}1445[1276- \\
1633]\end{array}$ \\
\hline & $\begin{array}{c}\text { Edoxaban } \\
50 \mathrm{ng} / \mathrm{mL}\end{array}$ & $\begin{array}{l}979[760- \\
1099]^{\star \star \star}\end{array}$ & $\begin{array}{c}976[878- \\
1239]^{*}\end{array}$ & $\begin{array}{c}964[873- \\
1083]^{* *}\end{array}$ & $\begin{array}{c}1245 \text { [1075- } \\
1344]\end{array}$ & $\begin{array}{c}1052 \text { [885- } \\
1369]\end{array}$ & $\begin{array}{c}1096 \text { [962- } \\
1302]\end{array}$ & $\begin{array}{c}1197 \text { [984- } \\
1505]\end{array}$ & $\begin{array}{c}1296[1144- \\
1466]\end{array}$ \\
\hline & $\begin{array}{l}\text { Edoxaban } \\
150 \mathrm{ng} / \mathrm{mL}\end{array}$ & $\begin{array}{l}750[496- \\
946]^{\star \star *}\end{array}$ & $\begin{array}{c}815[585- \\
1027] \text { * }\end{array}$ & $\begin{array}{c}861[761- \\
949]{ }^{*}\end{array}$ & $\begin{array}{c}1047 \text { [870- } \\
1143]\end{array}$ & $\begin{array}{c}722[645- \\
1163]\end{array}$ & $\begin{array}{c}959 \text { [729- } \\
1019]\end{array}$ & $\begin{array}{c}926 \text { [827- } \\
1198]\end{array}$ & $\begin{array}{c}1108 \text { [933- } \\
1225]\end{array}$ \\
\hline & $\begin{array}{l}\text { Edoxaban } \\
\text { 300ng/mL }\end{array}$ & $\begin{array}{c}572[333- \\
735]^{\star \star *}\end{array}$ & $\begin{array}{c}660[490- \\
823]^{*}\end{array}$ & $\begin{array}{c}702[611- \\
814]\end{array}$ & $\begin{array}{c}840 \text { [684- } \\
967]\end{array}$ & $\begin{array}{c}555[423- \\
944]^{*}\end{array}$ & $\begin{array}{c}865 \text { [513- } \\
907]\end{array}$ & $\begin{array}{c}772 \text { [618- } \\
986]\end{array}$ & $\begin{array}{c}928 \text { [692- } \\
1079]\end{array}$ \\
\hline \multirow{4}{*}{$\begin{array}{c}\text { Peak } \\
\text { (nM) }\end{array}$} & Vehicle & $\begin{array}{c}200[170- \\
262]^{* * *}\end{array}$ & $\begin{array}{c}193[160- \\
273]^{*}\end{array}$ & $\begin{array}{l}210[190- \\
243]^{*}\end{array}$ & $\begin{array}{c}275 \text { [215- } \\
316]\end{array}$ & $\begin{array}{c}245 \text { [206- } \\
282]\end{array}$ & $\begin{array}{c}250 \text { [196- } \\
283]\end{array}$ & $\begin{array}{c}258 \text { [217- } \\
334]\end{array}$ & $\begin{array}{c}285 \text { [245- } \\
319]\end{array}$ \\
\hline & $\begin{array}{c}\text { Edoxaban } \\
50 \mathrm{ng} / \mathrm{mL}\end{array}$ & $\begin{array}{l}104[68- \\
147]^{\star * *}\end{array}$ & $\begin{array}{c}117 \text { [96.6- } \\
198]\end{array}$ & $\begin{array}{c}118[90.5- \\
139]^{*} \\
\end{array}$ & $\begin{array}{c}148[108- \\
194]\end{array}$ & $\begin{array}{c}128[105- \\
173]\end{array}$ & $\begin{array}{c}147[105- \\
164]\end{array}$ & $\begin{array}{c}149[114- \\
205]\end{array}$ & $\begin{array}{c}173[134- \\
208]\end{array}$ \\
\hline & $\begin{array}{l}\text { Edoxaban } \\
150 \mathrm{ng} / \mathrm{mL}\end{array}$ & $\underset{* \star}{[34-83]}$ & 68 [49-91] & 71 [54-90] & 80 [66-110] & 60 [55-102] & 80 [60-95] & 79 [59-110] & 98 [75-127] \\
\hline & $\begin{array}{l}\text { Edoxaban } \\
\text { 300ng/mL }\end{array}$ & $\underset{\star \star \star}{40}[20-56]$ & 45 [40-64] & 53 [39-57] & 60 [45-73] & $43[33-71]$ & 60 [38-65] & 56 [40-74] & 67 [51-94] \\
\hline \multirow{3}{*}{$\begin{array}{l}\text { TTP } \\
(\min )\end{array}$} & Vehicle & 6.3 [5.4-7.3] & $6.1[5.4-8.5]$ & $6.4[4.7-6.7]$ & $5.8[5.4-6.7]$ & 6.5 [5.3-7.5] & $6.1[5.1-7.3]$ & $5.7[5.1-6.2]$ & $5.8[5.2-6.5]$ \\
\hline & $\begin{array}{c}\text { Edoxaban } \\
50 \mathrm{ng} / \mathrm{mL}\end{array}$ & $\begin{array}{c}11.3[9.46- \\
13.3]\end{array}$ & $\begin{array}{c}10.9[8.77- \\
11.7]\end{array}$ & $\begin{array}{c}10.8[8.17- \\
11.4]\end{array}$ & $\begin{array}{c}10[8.92- \\
11.1]\end{array}$ & $\begin{array}{c}11.4[10.2- \\
12.2]\end{array}$ & $\begin{array}{c}10.3[8.9- \\
12.2]\end{array}$ & $\begin{array}{c}9.67 \text { [8.7- } \\
11.9]\end{array}$ & $9.67[8.5-11]$ \\
\hline & Edoxaban & 16.3 [13.2- & 15.8 [13.3- & $16.2[11.2-$ & 15.0 [13.8- & $16.7[15.6-$ & 15.6 [14.3- & $15.2[12.5-$ & $14.3[12.3-$ \\
\hline
\end{tabular}




\begin{tabular}{l|c|c|c|c|c|c|c|c}
$150 \mathrm{ng} / \mathrm{mL}$ & $17.8]$ & $16.3]$ & $16.9]$ & $15.6]$ & $18.1]$ & $18]$ & $16.8]$ & $16.3]$ \\
\hline Edoxaban & $19.3[16.3-$ & $18.6[16.3-$ & $18.7[14.8-$ & $18.5[16.2-$ & $20.2[19.5-$ & $18.8[17.0-$ & $18.5[15.3-$ & $17.5[15.7-$ \\
$300 \mathrm{ng} / \mathrm{mL}$ & $22.3]$ & $19.3]$ & $20.2]$ & $19.3]$ & $21.2]^{*}$ & $20.9]$ & $20.8]$ & $19.3]$
\end{tabular}

Data are the median [Q1-Q3]

${ }^{* \star *} p<0.001,{ }^{* \star} p<0.01,{ }^{*} p<0.05$ compared with adults.

LT: Lag time; ETP: endogenous thrombin potential; TTP: Time to peak; yrs: years 
Figures

Figure 1: Relationship between edoxaban concentration and coagulation assay results in the different age groups.

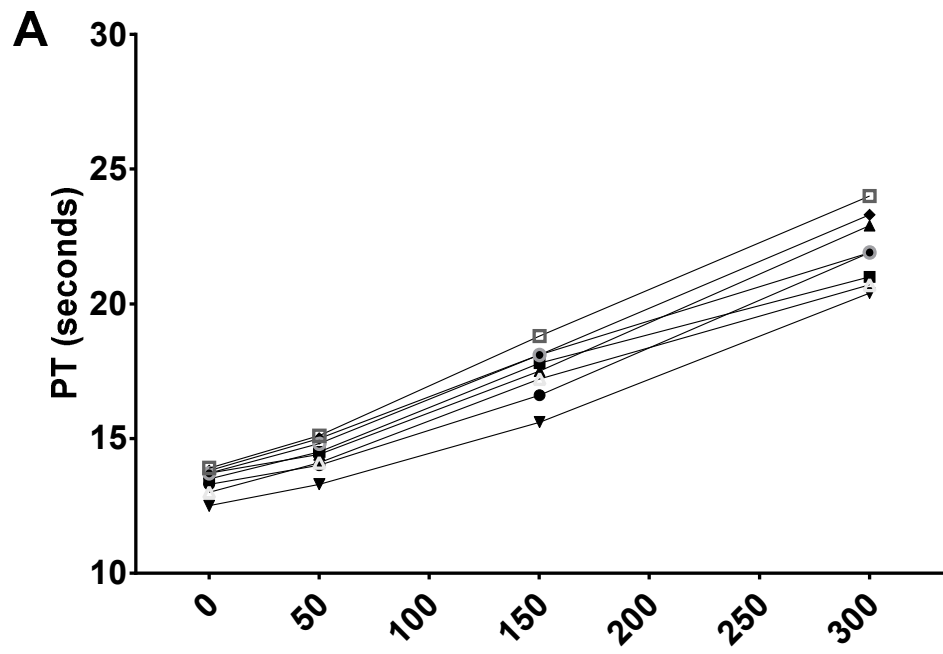

Edoxaban concentration $(\mathrm{ng} / \mathrm{mL})$

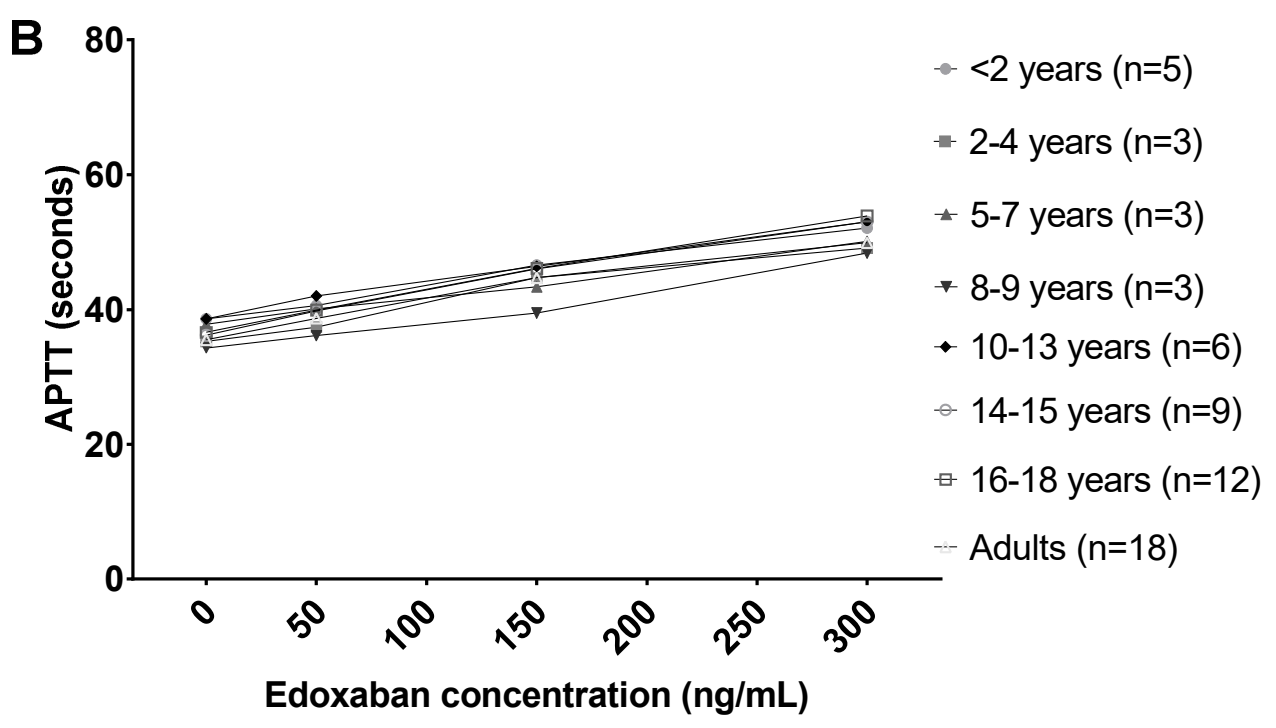

Edoxaban increased prothrombin time (PT) (A) and activated partial thromboplastin time $(\mathrm{aPTT})(\mathrm{B})$ in a concentration-dependent manner. The relationship was linear and the sensitivity to edoxaban was age-independent. Edoxaban had no effect on fibrinogen level, and fibrinogen concentration was comparable in adults and children. 
Figure 2: Relationship between edoxaban concentrations and specific anti-factor Xa assay results in the different age groups.

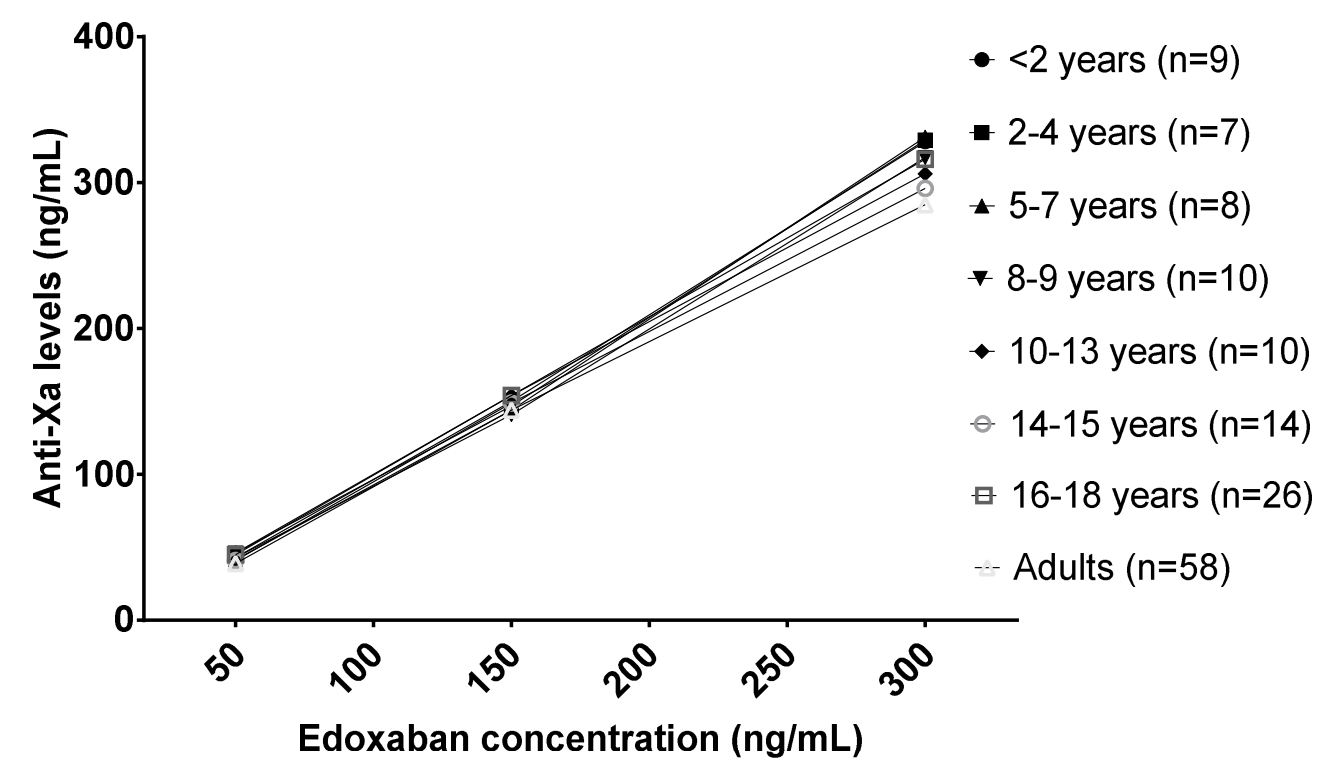

Edoxaban level in measured with a specific anti-factor Xa assay in plasma samples spiked with at 50,150 and $300 \mathrm{ng} / \mathrm{mL}$. No influence of age was observed. 
Figure 3: Effect of increasing concentrations of edoxaban on thrombin generation

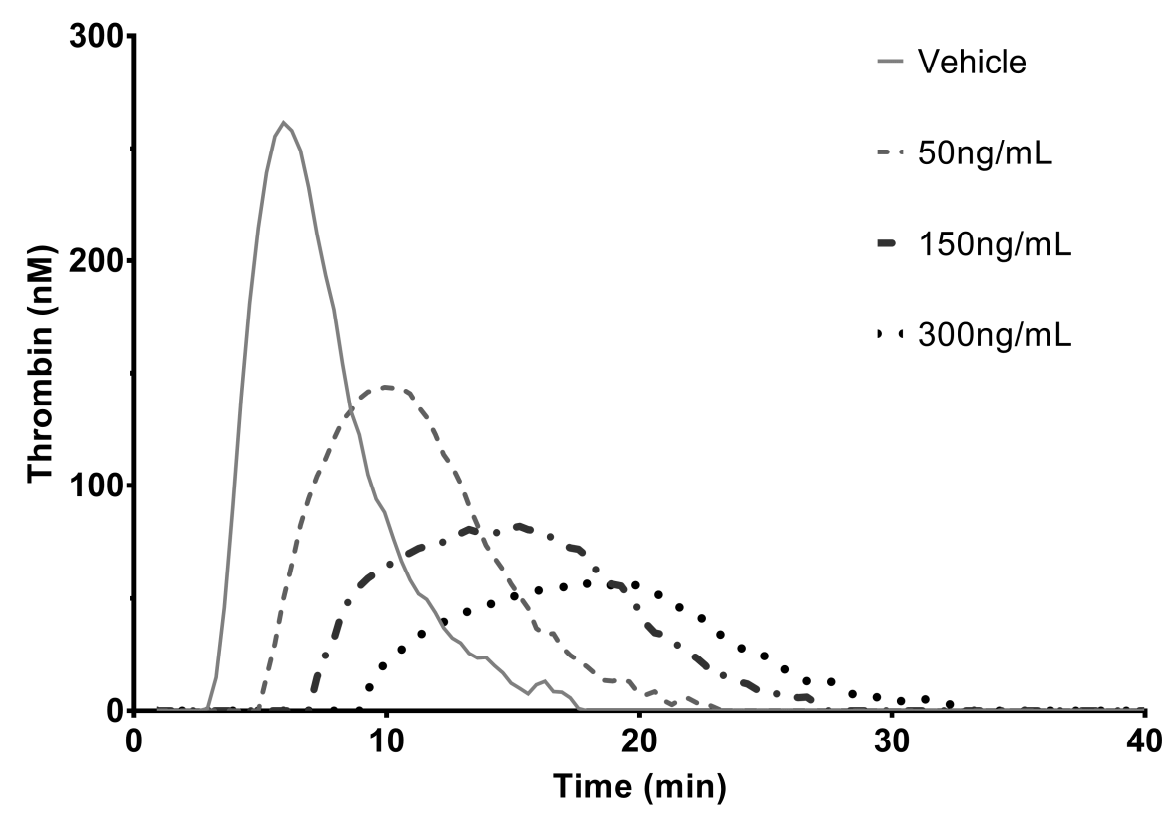

Thrombin generation assays were performed using platelet-poor plasma samples (with or without edoxaban) after addition of $5 \mathrm{pM}$ tissue factor and $4 \mu \mathrm{M}$ procoagulant phospholipids. Thrombin peak was the most sensitive parameter to edoxaban. 
Figure 4: Relationship between edoxaban concentrations and thrombin generation in the different age groups.

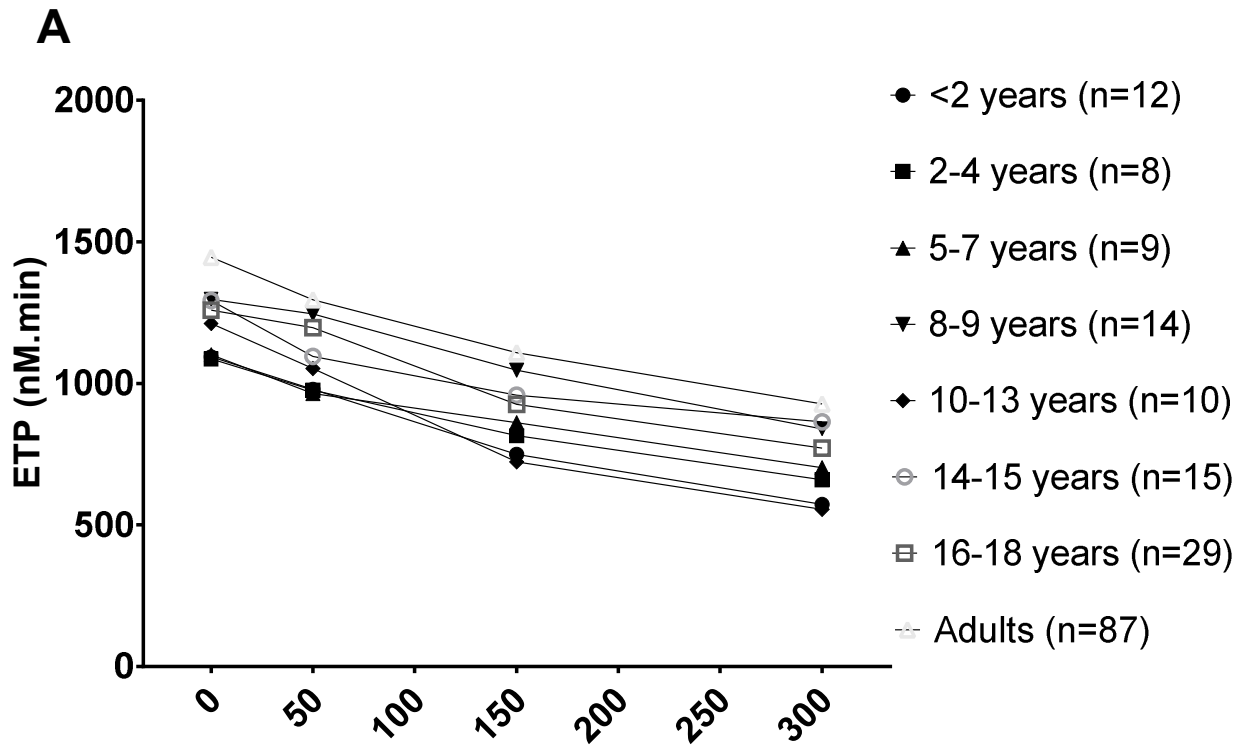

Edoxaban concentration $(\mathrm{ng} / \mathrm{mL})$

B

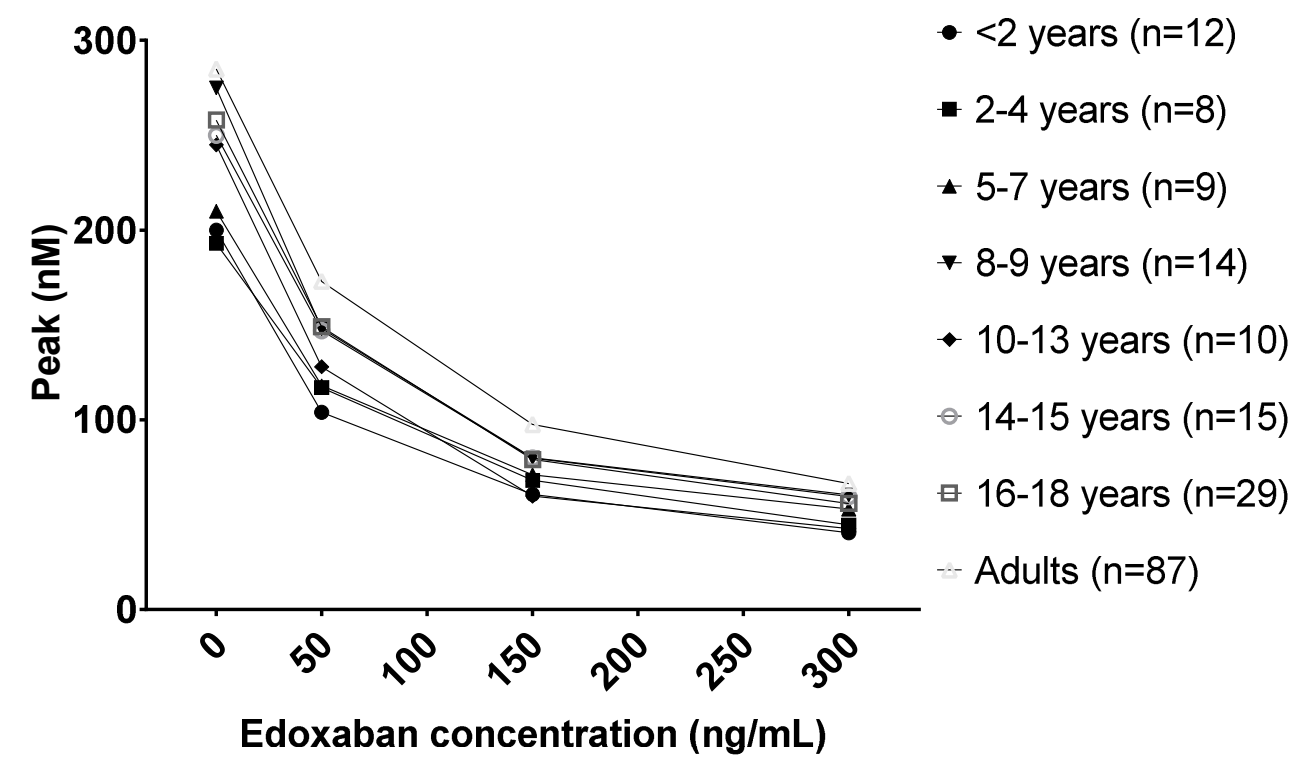

Edoxaban inhibited endogenous thrombin potential (ETP) (A) and thrombin peak (B) in a concentration-dependent manner. 
Figure 5: Percentage of thrombin peak inhibition by increasing edoxaban concentration in the different age groups.

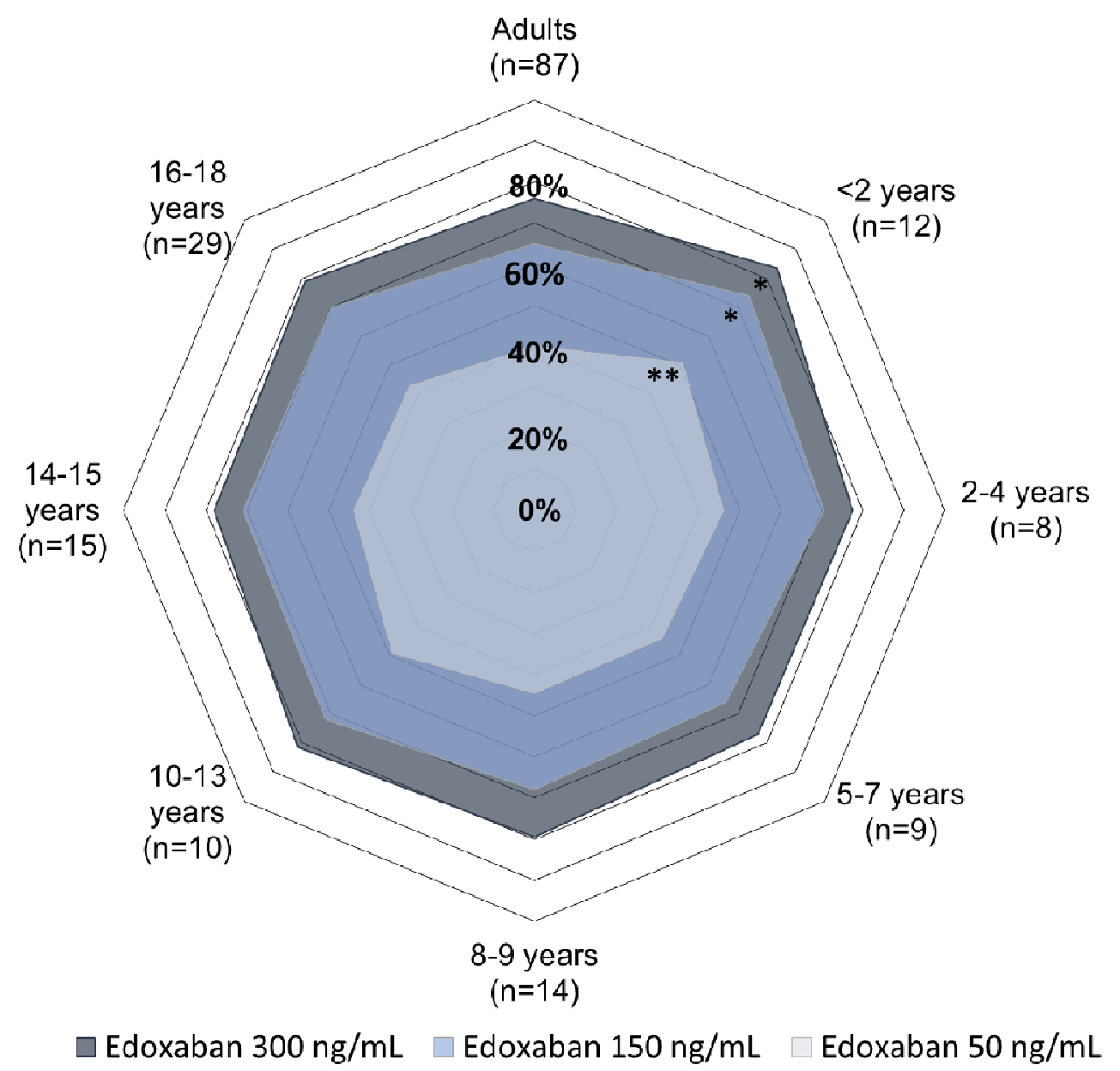

Radar chart showing the more pronounced inhibition of thrombin peak by edoxaban in the $<2$ year-age group compared with adults.

${ }^{* *} p<0.01,{ }^{*} p<0.05$ compared with adults 